\title{
Characterization of Polyphenol Oxidase Application as Phenol Removal in Extracts of Rejected White Oyster Mushrooms (Pleurotus ostreatus)
}

\author{
ANCEU MURNIATI ${ }^{*}$, BUCHARI BUCHARI ${ }^{2}$, SURYO GANDASASMITA ${ }^{2}$, \\ ZEILY NURACHMAN ${ }^{3}$ and NURY NURHANIFAH ${ }^{1}$
}

\begin{abstract}
${ }^{1}$ Analytical Chemistry Research Group, Faculty of Sciences and Informatics Universitas Jenderal Achmad Yani, Jl. Terusan Jenderal Sudirman, Cimahi, Indonesia. ${ }^{2}$ Analytical Chemistry Research Group, Faculty of Mathematics and Natural Sciences, Bandung Institute of Technology, Jl. Ganesha No. 10 Bandung 40132, Indonesia.

${ }^{3}$ Biochemistry Research Group, Faculty of Mathematics and Natural Sciences, Bandung Institute of Technology, Jl. Ganesha No. 10 Bandung 40132, Indonesia.

${ }^{*}$ Corresponding author E-mail: anceu.murniati@ lecture.unjani.ac.id
\end{abstract}

http://dx.doi.org/10.13005/ojc/340336

(Received: March 23, 2018; Accepted: May 09, 2018)

\section{ABSTRACT}

\begin{abstract}
Postharvest browning of edible mushrooms is related to oxidation of phenolic compounds by endogenous enzymes. Polyphenol oxidase (PPO) was isolated from rejected white oyster mushrooms (Pleurotus ostreatus) as a crude PPO extract using $50 \mathrm{mM}$ of citrate buffer at $\mathrm{pH} 7$ and $20^{\circ} \mathrm{C}$, which is active against phenol and catechol as substrates. PPO activity was $79.23 \mathrm{U} / \mathrm{mL}(0.3 \mathrm{mM}$ phenol) and $49.14 \mathrm{U} / \mathrm{mL}(0.2 \mathrm{mM}$ catechol) at initial rates measured using UV-Vis spectrophotometry. Protein content (using the Biuret method) in crude PPO extract was $3.15 \mathrm{mg} / \mathrm{mL}$, and the specific activity of PPO was $25.15 \mathrm{U} / \mathrm{mg}(0.3 \mathrm{mM}$ phenol) and $15.60 \mathrm{U} / \mathrm{mg}(0.2 \mathrm{mM}$ catechol). PPO extract was effective in reducing phenol content by 10.63 to $12.07 \%$ for each $5 \mathrm{~mL}$ of crude PPO extract added to an artificial solution containing $10.00 \mathrm{mg} / \mathrm{L}$ of phenol. In addition, Fourier transform infrared spectra of pure and crude PPO were analyzed based on protein functional groups. We conclude that white oyster mushroom PPO extracts may have a potential for removal of phenolic compounds in bioremediation and in the food and drug industries.
\end{abstract}

Keywords: Crude PPO extract, PPO activity, Specific activity, White oyster mushrooms, Phenol.

\section{INTRODUCTION}

Mushrooms are a special group of macroscopic fungi that have been used as a food source since ancient times. Oxidative browning of mushrooms involves the actions of a group of enzymes generally referred to as polyphenol oxidase (PPO) ${ }^{1}$ which, with phenolic 
compounds, are in general directly responsible for enzymatic browning reactions in damaged fruits during postharvest handling and processing. A relation between rate of browning, phenolic content, and PPO activity has been reported for various fruits ${ }^{1}$. PPO, also known as tyrosinase, phenolase, catechol oxidase, catecholase, o-diphenol oxidase, monophenol oxidase, and cresolase, was discovered in mushrooms in 1856 by Schoenbein ${ }^{2}$. PPO has the ability to oxidize phenols and thus cause browning of plant extracts and bruised plant tissues. In general, $\mathrm{PPO}$ is present in very high concentrations in plants, vegetables, and fruits such as mushrooms, potato tubers, apples, bananas, avocados, tea leaves, coffee beans, and tobacco leaves ${ }^{2}$. Melanins, produced as a consequence of PPO activity, may exhibit antibacterial, antifungal, anticancer, and antioxidant properties ${ }^{1}$. Plant PPOs have broad substrate specificities and are able to oxidize a variety of mono, di, or polyphenols. The mechanism of action proposed for PPO is based on its capacity to oxidize phenolic compounds ${ }^{3}$. PPO (EC 1.10.3.1; $o$-diphenol oxidoreductase) is an oxidoreductase capable of oxidizing phenol compounds by employing oxygen as a hydrogen acceptor ${ }^{1}$. The enzyme can use a number of monophenols and polyphenols plus oxygen as shown in equations 1 and $2^{2}$ :

phenol $+1 / 2 \mathrm{O}_{2} \rightarrow$ o-dihydroxyhenol

o-dihydroxyphenol $+1 / 2 \mathrm{O}_{2} \rightarrow$ o-benzoquinone $+\mathrm{H}_{2} \mathrm{O}$

PPO is included in the class of enzymes that have a copper dimer with histidine ligands in the active site, and the catalytic cycle of PPO has been investigated by Siegbahn ${ }^{4}$ and Klabunde et al., ${ }^{5}$ that reported the structure of PPO from sweet potato. Copper is a transition element frequently found at the active site of proteins, and copper-containing enzymes and proteins constitute an important class of biologically active molecules ${ }^{6}$. Mushroom PPO were subjected to further characterization studies in terms of biochemical characteristics and potential for biotechnological applications. Mushrooms contain a large amount of phenolic compounds which are readily oxidized during homogenization. After successive oxidation and polymerization of phenolic compounds in the mushroom extract, macromolecules of melanin are formed ${ }^{7,8}$. These melanin molecules have biochemical characteristic dependent on PPO activity, protein content, and specific activity, which has been studied in terms of substrate, optimum $\mathrm{pH}$, and incubation temperature using crude PPO. PPO, active between $\mathrm{pH} 5$ and 7 , does not have a very sharp $\mathrm{pH}$ optimum ${ }^{1}$. Because mushrooms are highly perishable commodities that start deteriorating immediately within a day after harvest ${ }^{9}$, PPO activity is studied to improve methods for controlling browning reactions, which is important to increase product value and minimize post-harvest losses ${ }^{3}$. Crude PPO extracts have been used in artificial solutions containing phenols. According to Aitken et al., ${ }^{10}$, these enzymes are highly selective biocatalysts and therefore have been proposed as a means to remove targeted substances from wastewaters. Phenolic compounds are major environmental pollutants because of their widespread use and potential toxicity to organisms, plants, and animals ${ }^{11,12}$. PPO may also find applications in the food or drug industries ${ }^{13}$. PPO can also be used for the bioremediation of phenolic contaminants from industrial wastewater ${ }^{12}$.

In this study, crude PPO extracts of rejected white oyster mushrooms were characterized in terms of PPO activity, protein quantity, and specific activity in a $50 \mathrm{mM}$ citrate buffer at varying $\mathrm{pH}$ and incubation temperatures.

\section{MATERIAL AND METHODS}

\section{Materials and Chemicals}

Rejected white oyster mushrooms (Pleurotus ostreatus) were obtained from Parongpong, Cimahi (West-Java Indonesia) and frozen at $-20^{\circ} \mathrm{C}$. Phenol and catechol were used as substrates. All chemicals used in this study were of analytical grade: bovine serum albumin (BSA), copper (II) sulfate pentahydrate, potassium sodium tartrate tetrahydrate $\left(\mathrm{KNaC}_{4} \mathrm{H}_{4} \mathrm{O}_{6}\right)$, 4-aminoantipyrine, potassium ferricyanide $\mathrm{K}_{3} \mathrm{Fe}(\mathrm{CN})_{6}$, ascorbic acid $\left(\mathrm{C}_{6} \mathrm{H}_{8} \mathrm{O}_{6}\right)$, EDTA $\left(\mathrm{C}_{10} \mathrm{H}_{16} \mathrm{~N}_{2} \mathrm{O}_{8}\right)$, sodium chloride ( $\mathrm{NaCl})$, Triton X-100 $\left(\mathrm{C}_{14} \mathrm{H}_{22} \mathrm{O}\left(\mathrm{C}_{2} \mathrm{H}_{4} \mathrm{O}\right) n\right)$, PVP $\left(\mathrm{C}_{6} \mathrm{H}_{9} \mathrm{NO}\right) \mathrm{n}$, ammonium hydroxide, cupric sulfate, and sodium hydroxide. All solutions were prepared with doubly distilled water. 
Preparation of Crude PPO Extract from White Oyster Mushroom

Rejected white oyster mushrooms (50 g) were cut into small pieces, dissolved in $50 \mathrm{~mL} 50$ $\mathrm{mM}$ citrate buffer (containing $0.5 \%(\mathrm{w} / \mathrm{v})$ triton $X-100$, $2 \mathrm{mM}$ EDTA, $1 \mathrm{M} \mathrm{NaCl}$, and $0.5 \%$ (w/v) PVP), and homogenized for $10 \mathrm{~min}$. at $4{ }^{\circ} \mathrm{C}$ at different $\mathrm{pH}$ (6.8, 7.0, and 7.2). The supernatant was filtered using a thin cloth and then centrifuged at $12.000 \mathrm{rpm}$ for 20 minutes. The supernatant containing PPO was used as the crude PPO extract, which was incubated for $30 \mathrm{~min}$ at different temperatures $(10,15,20,25$, and $30^{\circ} \mathrm{C}$ ).

\section{PPO Activity Assay}

PPO activity was determined using a spectrophotometric method ${ }^{2}$ with phenol and catechol as substrates as previously described ${ }^{14}$ and modified according to a Sigma procedure for commercial preparation ${ }^{15}$. Units of PPO activity were measured at initial rates and using a double beam UV-Vis-nir scanning spectrophotometer (UV-Vis 1800, Shimadzu).

Crude PPO extract $(0.1 \mathrm{~mL})$ was mixed with substrate at varying concentrations $(0.20-0.40$ $\mathrm{mM}$ ) and dissolved in $3 \mathrm{~mL}$ of $50 \mathrm{mM}$ citrate buffer containing $2.1 \mathrm{mM}$ ascorbic acid and $0.65 \mathrm{mM}$ EDTA. Optimum PPO activity was determined by varying $\mathrm{pH}$ (6.8- 7.2) and incubation temperature $\left(10-30{ }^{\circ} \mathrm{C}\right)$. PPO activity $(\mathrm{U} / \mathrm{mL})$ obtained in the assay was estimated by the initial rate of reaction and expressed as absorbance curve (A) vs time $(\mathrm{s})^{14}$. Multiplying the activity $(\mathrm{U} / \mathrm{mL})$ and total volume $(\mathrm{mL})$ gives the total activity $(\mathrm{U})^{16}$. Calculation of PPO activity is described in equation 3 , as follows:

PPO activity $=\frac{1}{\varepsilon b} \cdot \frac{\mathrm{V}_{\text {total }}}{\mathrm{V}_{\text {enzyme }}} \cdot \frac{\mathrm{d}[\text { substrate }]}{\mathrm{dt}}$

Where:

$\frac{1}{E b}=$ slope of absorbance vs [substrate] of standard curve of substrate

$\frac{d \text { [substrate ] }}{d t}=$ slope of absorbance vs time (min) of the initial rate

\section{Protein Content and Specific Activity}

Protein concentration in the white oyster mushroom extract was determined using the Biuret method with BSA as the standard solution ${ }^{16}$. Crude PPO extract $(1 \mathrm{~mL})$ was added to $9 \mathrm{~mL}$ of biuret reagent and incubated for $30 \mathrm{~min}$. and the absorbance curve was obtained spectrophotometrically at maximum wavelength of BSA. Protein content $(\mathrm{mg} / \mathrm{mL})$ was determined using a BSA standard curve (wavelength 400-600 nm). Total protein $(\mathrm{mg} / \mathrm{mL} \times \mathrm{mL}=\mathrm{mg})$ and specific activity $(\mathrm{U} / \mathrm{mg})$ were measured comparing PPO activity $(\mathrm{U} / \mathrm{mL})$ and protein content $(\mathrm{mg} / \mathrm{mL})^{16}$.

\section{Removal of Phenolic Compounds using White Oyster Mushroom Extracts}

Removal of phenolic compounds using crude PPO extracts was measured using the 4-aminoantipyrine method and UV-Vis spectrophotometry ${ }^{17}$, with modifications. Artificial solution containing $10 \mathrm{mg} / \mathrm{L}$ phenol were placed into ten $250-\mathrm{mL}$ beaker glasses. To each solution was added crude PPO extract ( 0.50 to $50.00 \mathrm{~mL}$ ). The mixtures were centrifuged to remove the precipitate formed, let stand for $24 \mathrm{~h}$, and then dissolved in 100 $\mathrm{mL}$ of $50 \mathrm{mM}$ citrate buffer solution $\mathrm{pH} 7(2.5 \mathrm{~mL}$ of $0.5 \mathrm{~N} \mathrm{NH}_{4} \mathrm{OH}, 1 \mathrm{~mL}$ of 4-aminoantipyrine, and $1 \mathrm{~mL}$ of $\mathrm{K}_{3} \mathrm{Fe}(\mathrm{CN})_{6}$ ). Sample absorbance was measured spectrophotometrically using the standard curve and the phenol concentration $(\mathrm{mg} / \mathrm{L})$ was calculated.

\section{RESULTS AND DISCUSSION}

\section{PPO Activity in Crude PPO Extract}

Polyphenol Oxidase crude extracts were successfully produced with a yield of as much as $80 \%$ of the initial amount $(50 \mathrm{~mL})$ of rejected white oyster mushroom $(50 \mathrm{~g})$ by homogenization and centrifugation. Mushrooms (50 g/50 mL) were homogenized with the same composition as previously described ${ }^{18}$. Units of PPO activity were determined using the initial rates method by measuring changes in substrate concentration because enzyme behavior often follows hyperbolic Michaelis-Menten kinetics $^{19}$, where the initial rate of the enzymatic reaction is proportional to the concentration of the enzyme ${ }^{7}$.

Polyphenol Oxidase and total activities in white crude PPO extracts using phenol and catechol as substrates at varying concentrations and $\mathrm{pH}$ are shown in Fig. 1 and 2. The highest PPO $(79.23 \mathrm{U} / \mathrm{mL}$, $3961.50 \mathrm{U}, 0.30 \mathrm{mM}$ phenol) and total $(49.14 \mathrm{U} / \mathrm{mL}$; 
$2457 \mathrm{U} ; 0.20 \mathrm{mM}$ catechol) activities were achieved at $50 \mathrm{mM}$ of citrate buffer solution and $\mathrm{pH}$ 7.0. PPO activity can be observed based on equation 3 and can be monitored from the curve of the initial rates of spectrophotometry data of absorbance versus time as shown in Fig. 3(i) and 3(ii). PPO activity can be monitored of the decrease of concentration of phenol and cathecol using PPO extract at $\mathrm{pH}$ 7.0. In our results, rejected white oyster mushroom extracts showed a higher PPO activity with phenol compared to catechol as substrate, thus affecting protein content and specific activity. Therefore, PPOs from new sources are useful to explain their biochemical properties and behavior ${ }^{13}$. Haghbeen et al., ${ }^{8}$ have described crude PPO extracts from edible mushroom using $410 \mathrm{~mL} 10 \mathrm{mM}$ of phosphate buffer solution with an optimum $\mathrm{pH}$ of $6.8(0.87 \mathrm{U} / \mathrm{mL}$, $1640.00 \mathrm{U}, 0.3 \mathrm{mM}$ phenol). Previous findings were identical to that reported by Öz et al., ${ }^{13}$ with respect to optimum $\mathrm{pH}(7.0)$ and temperature $\left(20^{\circ} \mathrm{C}\right)$ of purified PPO of Lactarius piperatus using catechol as substrate. An optimum $\mathrm{pH}$ of 7.0 for tyrosinase from Agaricus bisporus using phosphate buffer was also reported ${ }^{7}$.

Calculation of PPO activity is described in equation 3 , one unit $(U)$ of PPO activity is defined as the amount of enzyme that decreases the concentration of substrate by one $\mu \mathrm{mol}$ per min. with a corresponding change in absorbance $(A=0.001$; PPO $\lambda \max =257.2 \mathrm{~nm}$ ) as shown in Fig. 3 (i) and 3 (ii). The kinetic properties of the initial rate can be observed in the graphs of absorbance vs [phenol] (phenol $\lambda$ maks $=258.8 \mathrm{~nm}$; standard curve equation: $\left.1.493 x+0.008 ; R^{2}=0.99\right)$ and of absorbance vs catechol (catechol $\lambda$ maks $=269.8 \mathrm{~nm}$; standard curve equation: $\left.y=2.220 x+0.026 ; R^{2}=0.99\right)$.

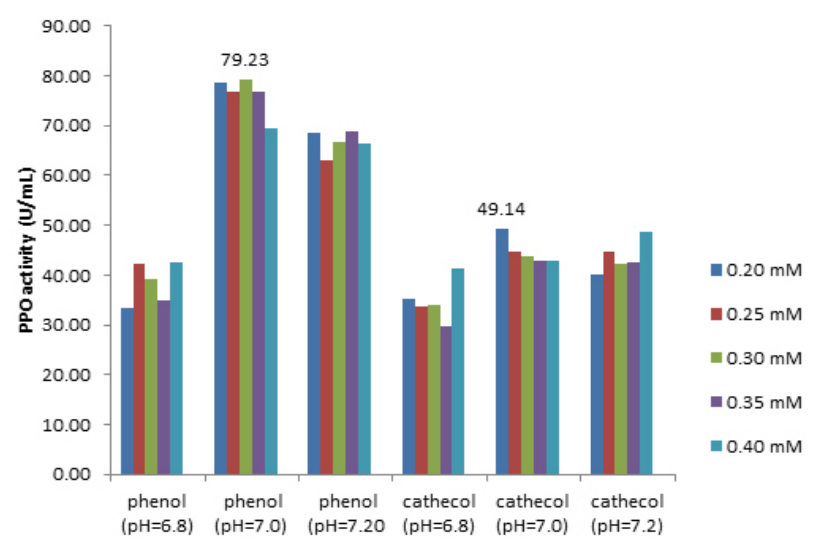

Fig. 1. Profile of polyphenol oxidase (PPO) activity $(\mathrm{U} / \mathrm{mL})$ in crude PPO extracts using phenol and catechol as substrates at different $\mathrm{pH}(6.8,7.0$, and 7.2$)$.

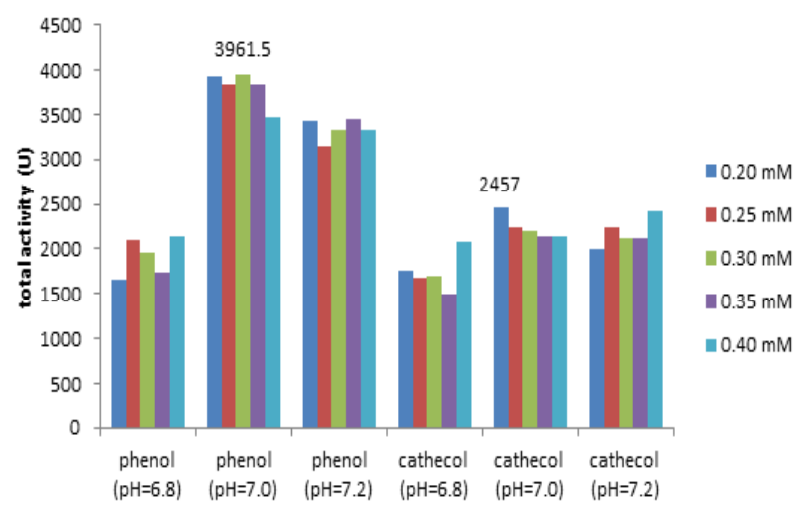

Fig. 2. Profile of total activity $(U)$ in crude polyphenol oxidase extracts using phenol and catechol as substrates at different $\mathrm{pH}(6.8,7.0$, and 7.2$)$. 


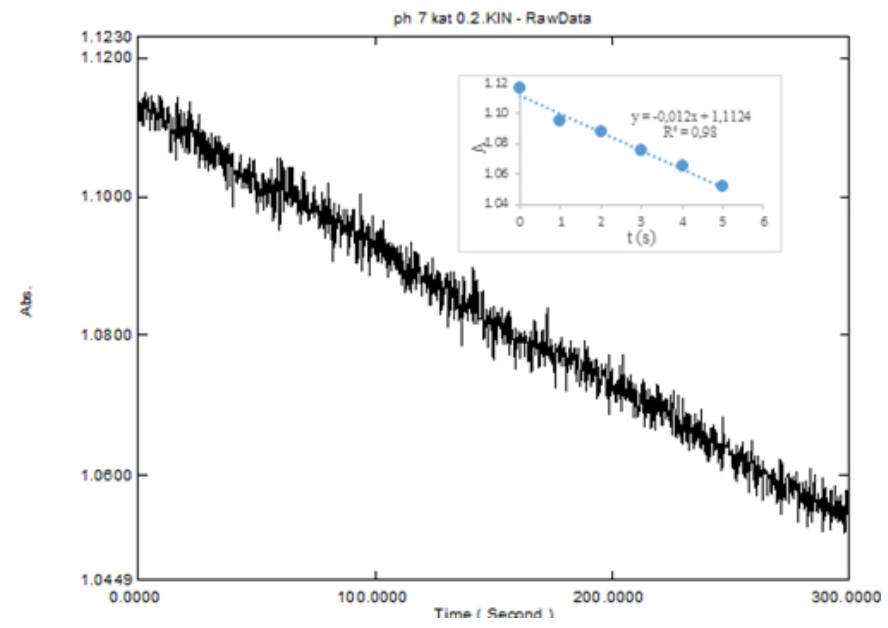

(a)

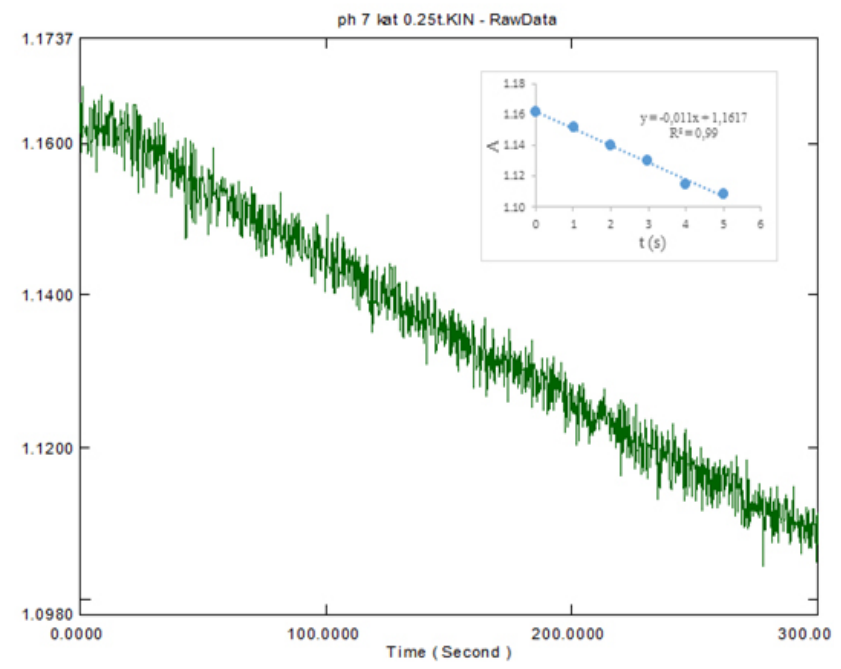

(b)

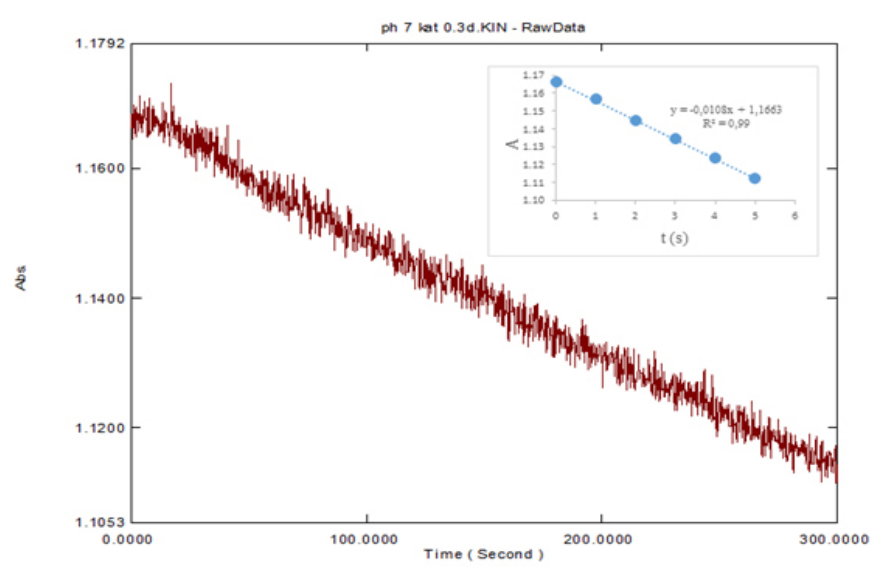

(c) 


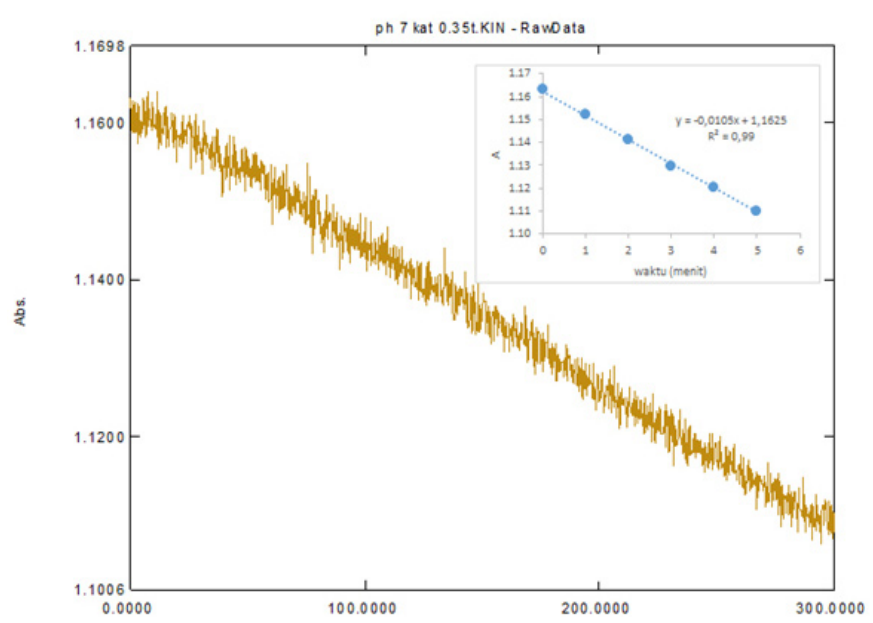

(d)

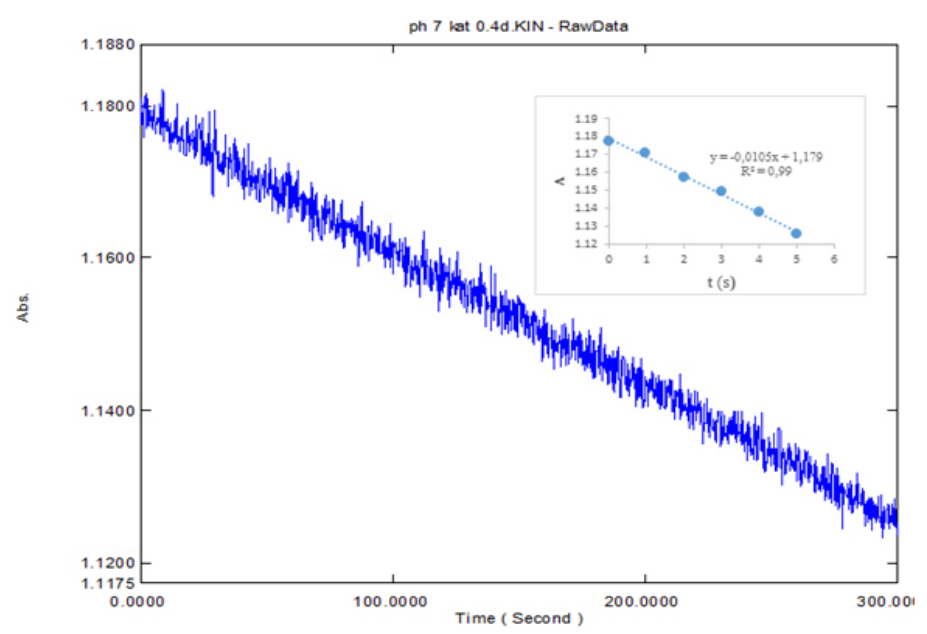

(e)

Fig. 3 (i). The initial rates of spectrophotometry data of absorbance (A) versus time (t). Monitoring the decrease of concentration of phenol using crude polyphenol oxidase extract at pH 7.0; PPO $\lambda \max =257.2 \mathrm{~nm}(\mathrm{a}) .0 .2$ mM phenol; (b). $0.25 \mathrm{mM}$ phenol; (c). $0.30 \mathrm{mM}$ phenol ; (d). $0.35 \mathrm{mM}$ phenol (a). $0.40 \mathrm{mM}$ phenol

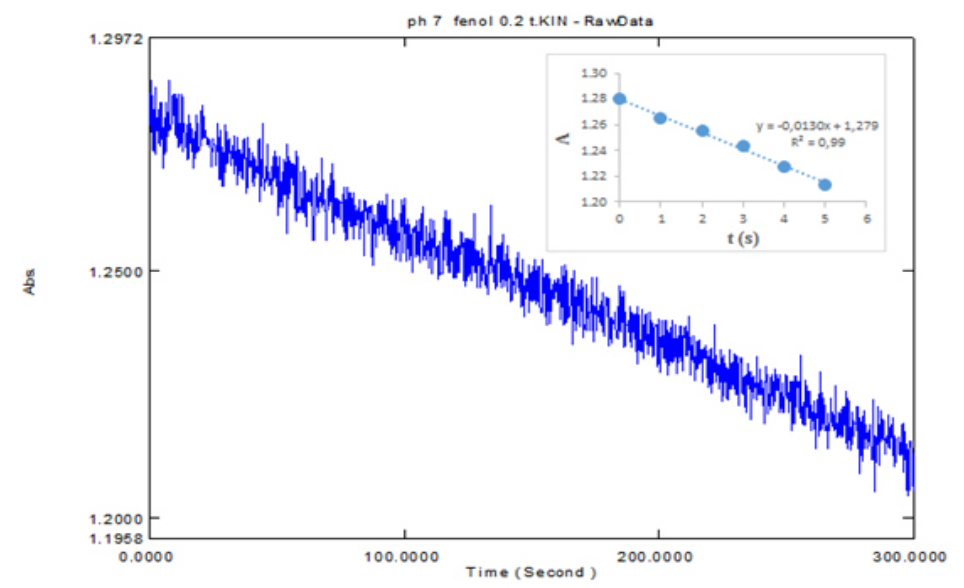

(a) 


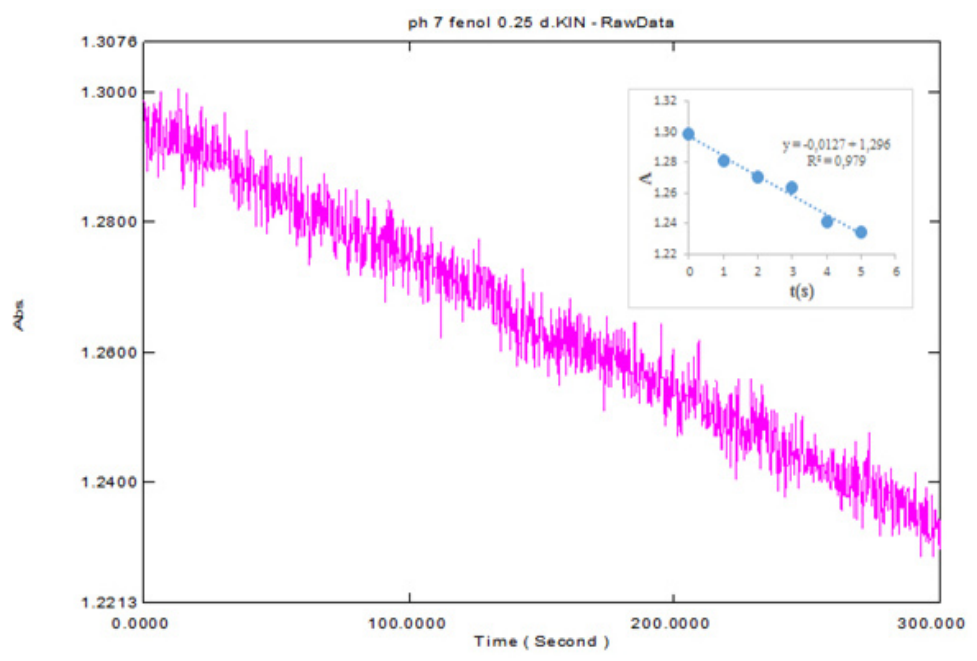

(b)

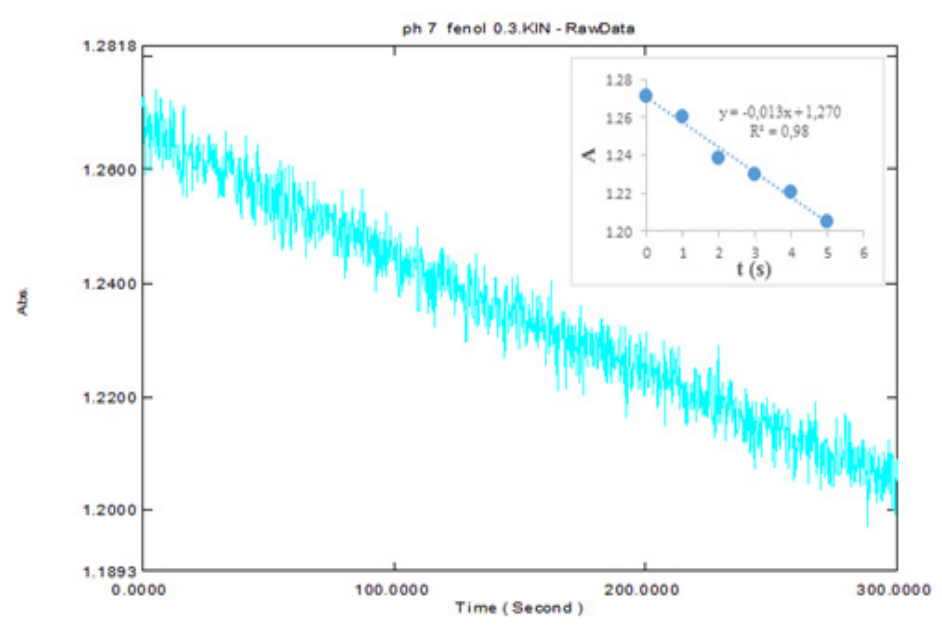

(c)

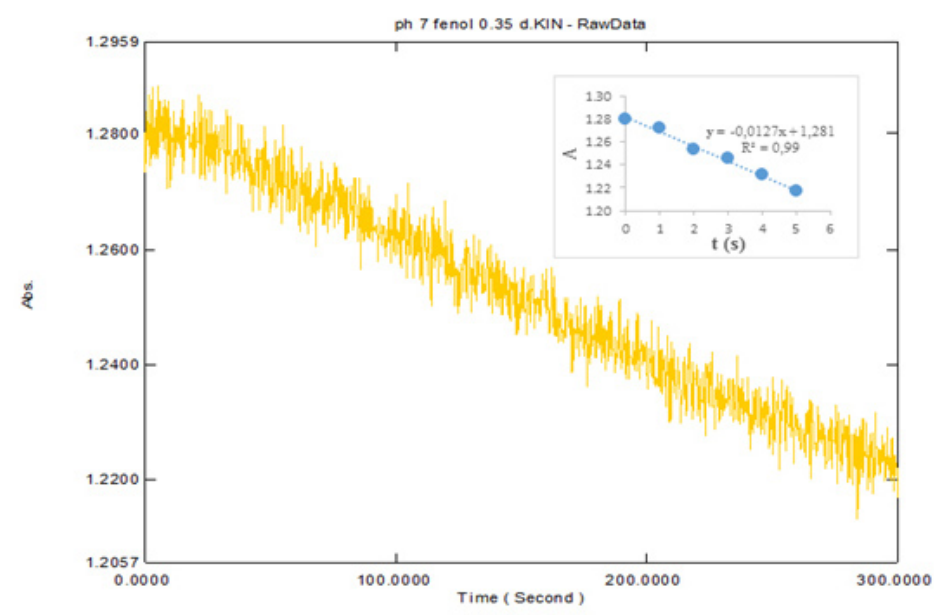

(d) 


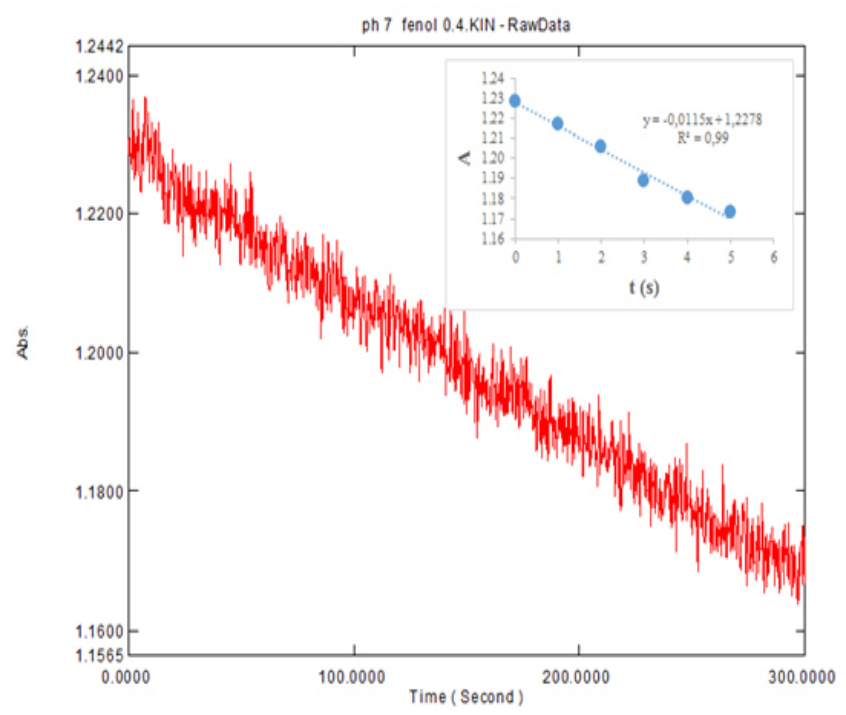

(e)

Fig. 3 (ii). The initial rates of spectrophotometry data of absorbance (A) versus time (t). Monitoring the decrease of concentration of phenol using using crude polyphenol oxidase extract at pH 7.0; PPO $\lambda \mathrm{max}=257.2 \mathrm{~nm}$ (a). $0.2 \mathrm{mM}$ catechol; (b). $0.25 \mathrm{mM}$ catechol ; (c). $0.30 \mathrm{mM}$ catechol ; (d). $0.35 \mathrm{mM}$ catechol (a). $0.40 \mathrm{mM}$ catechol

Protein Content and Specific Activity in White Oyster Mushroom Extract

Colorimetric methods exploit the properties of specific proteins, the presence of specific amino acid functional groups, or the presence of peptide bonds ${ }^{1}$. Protein content and total protein in white oyster mushroom extracts were determined as $3.15 \mathrm{mg} / \mathrm{mL}$ and $157.5 \mathrm{mg}$, respectively, using the Biuret method and a standard curve $(\lambda \max =540$ $\mathrm{nm}$; standard curve equation: $\mathrm{y}=0.2455+0.1567$; $R=0.99$ ). The specific activity profile is shown in Fig. 4. The highest specific activity was achieved under optimal conditions of $\mathrm{pH} 7.0$ and enzyme and substrate concentrations $(25.15 \mathrm{U} / \mathrm{mg}$ and $0.3 \mathrm{mM}$ phenol; $15.60 \mathrm{U} / \mathrm{mg}$ and $0.2 \mathrm{mM}$ catechol).

Öz et al., ${ }^{13}$ determined the protein contents in PPO crude mushroom extracts to be an average of $0.18 \pm 0.02 \mathrm{mg} / \mathrm{mL}$ using a BSA standard $(\lambda \max =$ $650 \mathrm{~nm}$ ) and the Lowry method. We found the specific activity of crude PPO extract and purified PPO to be 1.92 and $26.67 \mathrm{U} / \mathrm{mg}$, respectively. Zaidi et al., ${ }^{7}$ reported the total protein, PPO activity, total activity, and specific activity of crude PPO extract from button mushroom to be $321.40 \mathrm{mg}$, $2.56 \mathrm{U}, 1021 \mathrm{U}$, and $3.189 \mathrm{U} / \mathrm{mg}$, respectively.

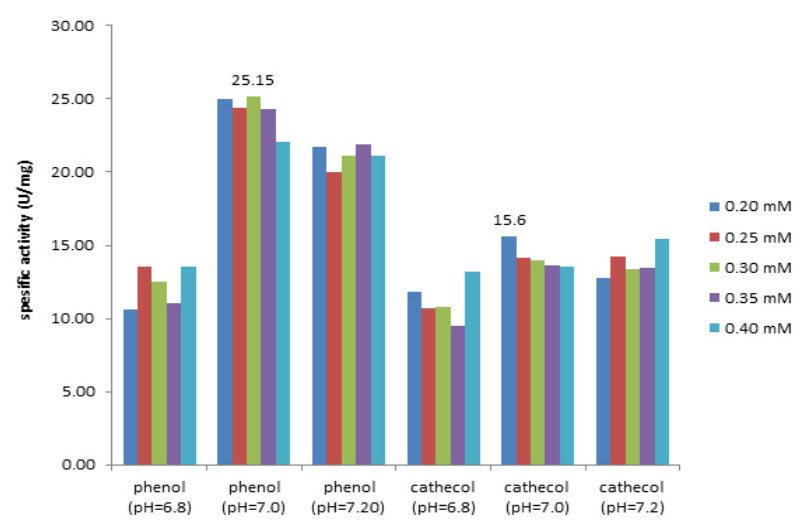

Fig. 4. Profile of specific activity (U/mg) in crude polyphenol oxidase extracts using phenol and catechol as substrates at different $\mathrm{pH}(6.8,7.0$, and 7.2$)$. 


\section{Thermal Stability of PPO}

Temperature and $\mathrm{pH}$ also affect PPO activity 2. Our results show that incubation temperature $\left(10-30{ }^{\circ} \mathrm{C}\right)$ affected the activity and specific activity of crude PPO extracts. Fig. 5 shows the effect of incubation temperature on PPO activity using phenol and catechol as substrates $(0.20-0.40 \mathrm{mM})$. The highest PPO activity was observed under optimal conditions of $20^{\circ} \mathrm{C}, \mathrm{pH} 7$, and extract and substrate concentrations $(79.23 \mathrm{U} / \mathrm{mL}$ and $0.3 \mathrm{mM}$ phenol; $49.11 \mathrm{U} / \mathrm{mL}$ and $0.20 \mathrm{mM}$ catechol). This effect can also be observed in the chart of temperature $\left({ }^{\circ} \mathrm{C}\right)$ vs total activity $(\mathrm{U})$ using phenol and catechol as substrates, as shown in Figure 6 . At $20^{\circ} \mathrm{C}$, the optimum temperature, total PPO activity against phenol and catechol was 3961.5 and $2455.5 \mathrm{U}$, respectively. In addition, at $\mathrm{pH} 7$, the chart of specific activity vs. incubation temperature in Fig. 7 shows that the highest value was achieved at $20^{\circ} \mathrm{C}$ (25.15 U/mg and $15.59 \mathrm{U} / \mathrm{mg}$ with phenol and catechol as substrates, respectively).

Thermal stability of crude PPO extracts was achieved at $20{ }^{\circ} \mathrm{C}(25.15 \mathrm{U} / \mathrm{mg}, 0.30 \mathrm{mM}$ phenol; $15.60 \mathrm{U} / \mathrm{mg}, 0.20 \mathrm{mM}$ catechol). These results are consistent with those of Öz et al., ${ }^{13}$, who described the optimum temperature of L. piperatus PPO as $20^{\circ} \mathrm{C}$ when assayed between 10 and $80^{\circ} \mathrm{C}$ using catechol as substrate.

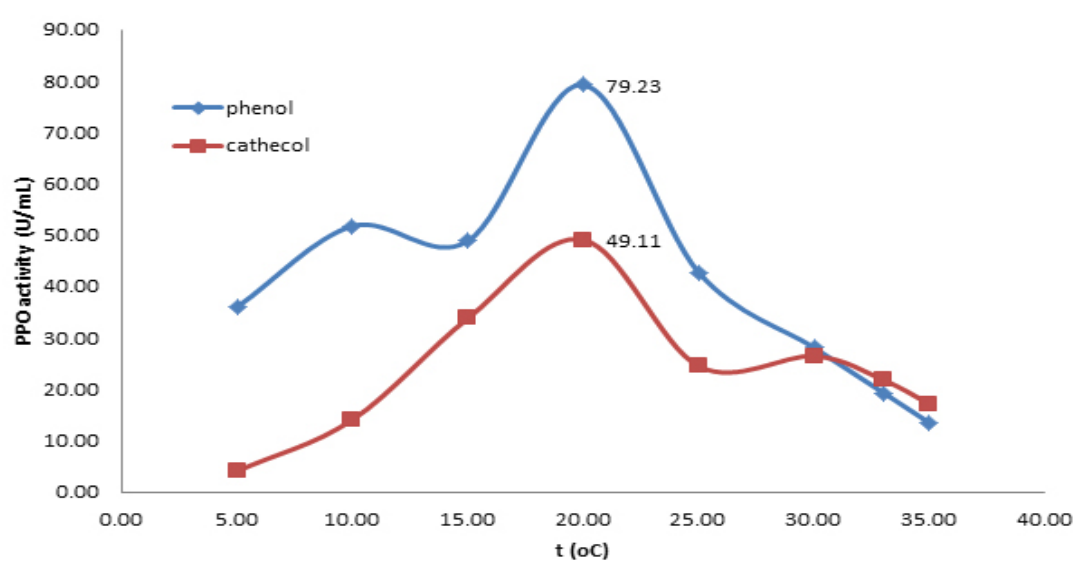

Fig. 5. Effect of temperature $\left({ }^{\circ} \mathrm{C}\right)$ on polyphenol oxidase activity $(\mathrm{U} / \mathrm{mL})$ using phenol and catechol as substrates

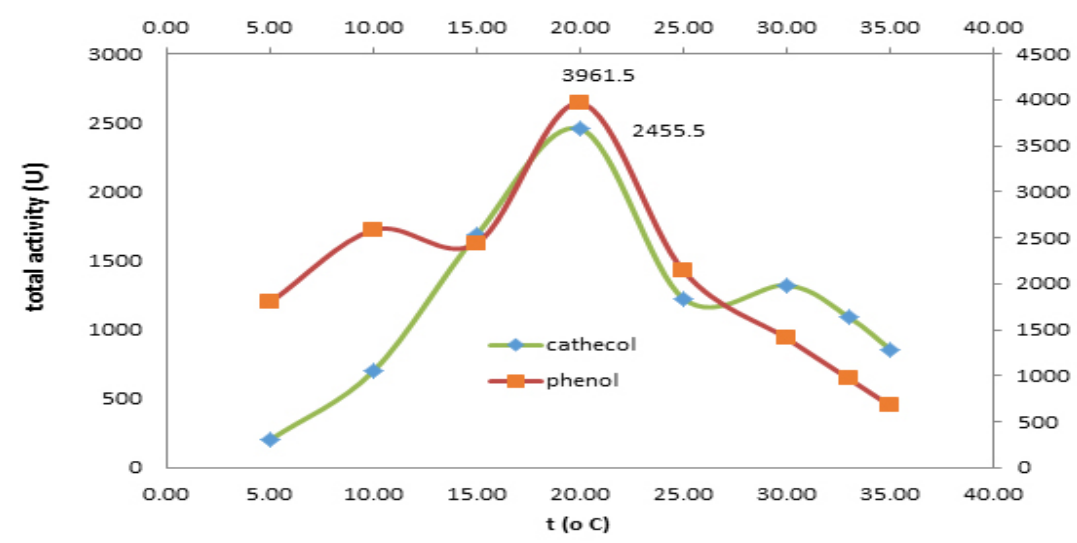

Fig. 6. Effect of temperature $\left({ }^{\circ} \mathrm{C}\right)$ on polyphenol oxidase total activity $(\mathrm{U})$ using phenol and catechol as substrates.

Removal of Phenolic Compounds using Crude PPO Extract

Table 1 shows the reduction of phenol concentration in an artificial solution containing 10.00 $\mathrm{mg} / \mathrm{L}$ of phenol with the addition of crude PPO extract (0.50 to $50.00 \mathrm{~mL}$ ) under optimal conditions $(\mathrm{pH} \mathrm{7.0}$; 


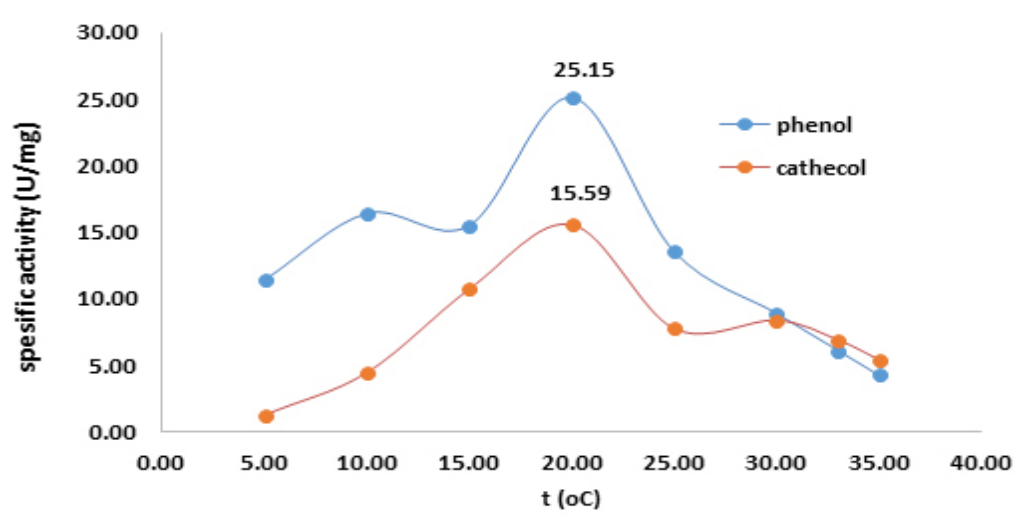

Fig. 7. Effect of temperature $\left({ }^{\circ} \mathrm{C}\right)$ on polyphenol oxidase specific activity (U/ $\mathrm{mg}$ ) using phenol and catechol as substrates.

$20{ }^{\circ} \mathrm{C} ; 25.15 \mathrm{U} / \mathrm{mg}$ of PPO as specific activity). It can be seen that increased volumes of crude PPO extract led to reduced phenol content in the artificial wastewater as measured by the conversion of phenol to quinone. PPO extract as a biocatalyst worked effectively in catalyzing phenol to quinone: each $5 \mathrm{~mL}$ of crude PPO extract resulted in a decrease in phenol content in the range of 10.63 to $12.07 \%$. Thus, the effect of increasing the volume of crude PPO extract even further could be studied in detail. The addition of 10 to $15 \mathrm{~mL}$ of crude PPO extract with $79.23 \mathrm{U} / \mathrm{mL}$ activity to the artificial solution demonstrated PPO as increasingly effective in the oxidation of phenol

Table 1: Removal of phenol from an artificial solution (10.00 $\mathrm{mg} / \mathrm{L})$ catalyzed using crude polyphenol oxidase extract with specific and total activities of $79.23 \mathrm{U} / \mathrm{mL}$ and $3961.50 \mathrm{U}$, respectively.

\begin{tabular}{ccc}
\hline $\begin{array}{c}\text { crude PPO } \\
\text { extract } \\
(\mathrm{mL})\end{array}$ & $\begin{array}{c}\text { phenol } \\
(\mathrm{mg} / \mathrm{mL})\end{array}$ & $\begin{array}{c}\text { removal of } \\
(\%) \text { phenol }\end{array}$ \\
\hline- & 10.00 & 0.05 \\
0.50 & 9.70 & 7.42 \\
1.00 & 8.44 & 19.42 \\
2.00 & 7.18 & 31.49 \\
5.00 & 6.16 & 41.18 \\
10.00 & 5.05 & 51.81 \\
15.00 & 3.94 & 62.45 \\
20.00 & 2.82 & 73.08 \\
25.00 & 1.71 & 83.71 \\
50.00 & 0.59 & 94.35 \\
\hline
\end{tabular}

to quinone at levels above $50 \%$. Furthermore, addition of 20 to $50 \mathrm{~mL}$ led to a reduction in phenol concentration of up to $90 \%$ (10 mg/L phenol in 50 $\mathrm{mM}$ citrate buffer $\mathrm{pH}$ 7.0). Edalli \& Kamanavalli11 reported that crude PPO extracts can be used in the detection and removal of phenols from domestic and industrial wastewater. The authors showed that crude PPO extract with $1800 \mathrm{U} / \mathrm{mL}$ activity was effective in degrading $100 \%$ of phenol (50 mg/L phenol in 50 $\mathrm{mM}$ phosphate buffer $\mathrm{pH} 8.0$ ).

The further research for scale-up investigations, it needs to be studied the performance of crude PPO extract to degradate from industrial waste contaminated phenol. The effectiveness of PPO performance in the process of degradation of phenol to quinone, is expected to be more effective, when PPO is immobilized in a polypyrrole (PPy) film. The thin PPy film has been studied on the steel gauze by electropolimerization with cyclic voltammetry in 10 cycles of cyclic voltammogram ${ }^{20}$. Meanwhile, immobilization of PPO in PPy thin film can be studied based on the strength of PPO as dopant during electropolymerization process of PPy film growth as modified $\mathrm{PPy}^{21}$.

Fourier Transform Infrared (FTIR) Spectroscopy Analysis of PPO in White Oyster Mushroom Extract

The FTIR spectra profile of crude PPO extract is shown in Fig. 8. FTIR analysis of pure PPO and PPO extracts was performed based on protein function groups ${ }^{22}$ : $-\mathrm{OH}\left(3446.79 \mathrm{~cm}^{-1} \mathrm{vs}\right.$. 
$\left.3429.43 \mathrm{~cm}^{-1}\right), \mathrm{CH}\left(3100.00 \mathrm{~cm}^{-1}\right.$ vs. $\left.2962 \mathrm{~cm}^{-1}\right), \mathrm{C}=\mathrm{O}$ $\left(1750.00 \mathrm{~cm}^{-1}\right.$ vs. $\left.1624.06 \mathrm{~cm}^{-1}\right), \mathrm{C}=\mathrm{C}\left(1635.64 \mathrm{~cm}^{-1}\right.$ vs. $\left.1406.11 \mathrm{~cm}^{-1}\right)$, and CN $\left(1161.15 \mathrm{~cm}^{-1}\right.$ vs. 1298,09 $\left.\mathrm{cm}^{-1}\right)$. The wave number shifts presumably occurred because of the influence of other matrices contained in white mushroom extracts.

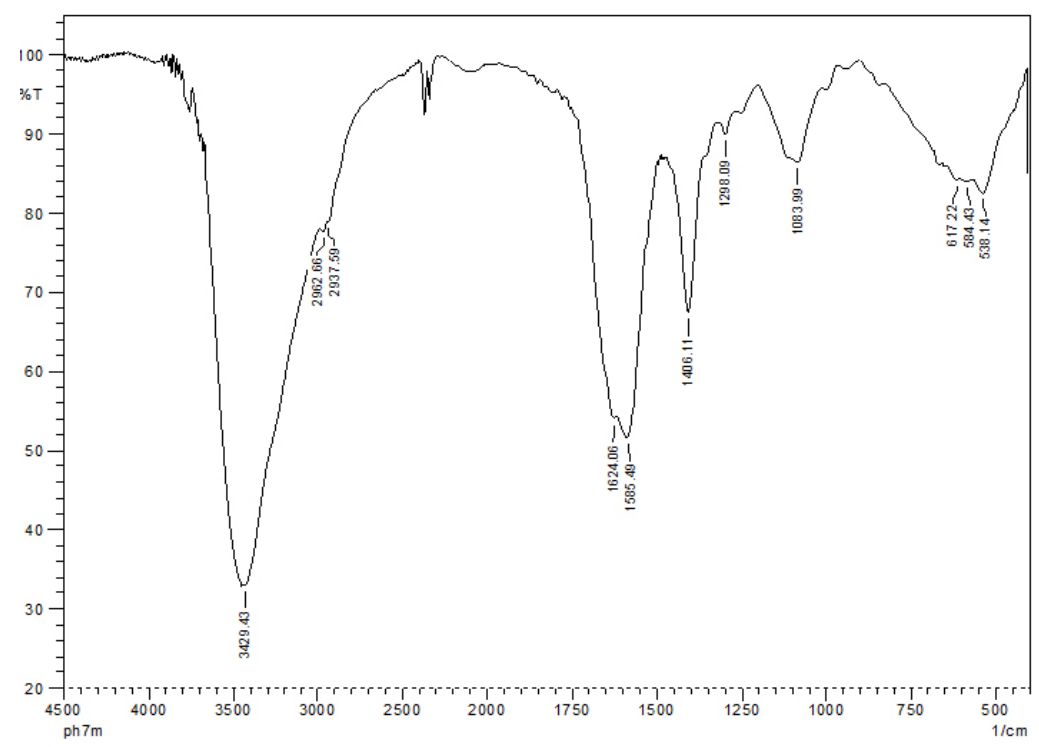

Figure 8. Fourier transform infrared spectra of crude polyphenol oxidase extract

\section{CONCLUSION}

Crude PPO extracts from were obtained with a yield of as much as $80 \%$ of the initial amount $(50 \mathrm{~g} / 50 \mathrm{~mL})$. The biochemical characteristics of PPO in these extracts were studied by monitoring their activity (activity, total activity, protein content, total protein, and specific activity) using phenol and catechol as substrates. PPO activity was higher with phenol as substrate. The optimal conditions for the crude PPO extract were a buffer citrate solution at $\mathrm{pH} 7$ and $20^{\circ} \mathrm{C}$. In addition, crude PPO extract activity converted more than $90 \%$ of phenol to quinone in an artificial solution containing $10 \mathrm{mg} / \mathrm{L}$ of phenol. PPO extracts from white oyster mushrooms may thus have a potential for removal of phenolic compounds in bioremediation and in the food and drug industries. Further research is needed for the effective performance of crude PPO extract in the degradation of phenol wastewater.

\section{ACKNOWLEDGEMENT}

This research was supported by the Ministry of Finance, Republic of Indonesia for RISPRO LPDP (RPI-PRJ-642/LPDP/2016 for AM Research Group) and Hibah Kompetitif LPPM Unjani 2017 (Skep 133/ UNJANI/VI/2017 for AM Research group).

\section{REFERENCES}

1. Simpson, B. K. Food Biochemistry and Food Biochemistry, (1st ed). USA: A john Willey \& sons, Ltd. Publication., 2012.

2. Whitaker, J. Handbook of Food Enzymology, (1st ed). New York Basel:Marcel Dekker, Inc., 2003.

3. Queiroz, C.; Mendes Lopes, M.L.; Fialho, E.; Valente-Mesquita, V. L.; Polyphenol Oxidase: Characteristics and Mechanisms of Browning
Control. Food Rev. Int., 2008, 24, 361-375.

4. Siegbahn, P. E. M., The Catalytic Cycle of Catechol Oxidase. J. Biol. Inorg. Chem., 2004, 9, 577-590.

5. Klabunde, T.; Eicken, C.; Sacchettini, J. C.; Krebs, B., Crystal Structure of A Plant Catechol Oxidase Containing a Dicopper Center. Nat. Struct. Biol., 1998, 5, 10841090. 
6. Mukherjee, R. N., The Bioinorganic Chemistry of Copper. Indian J. Chem. - Sect. A Inorganic., Phys. Theor. Anal. Chem., 2003, 42, 2175-2184.

7. Zaidi, K. U.; Ali, A. S.; Ali, S. A., Purification and Characterization of Melanogenic Enzyme Tyrosinase from Button Mushroom. Enzyme Res., 2014, 2014, 1-6.

8. Haghbeen, K.; Jazii, F. R.; Karkhane, A. A., Purification of tyrosinase from edible mushroom. Iran. J. Biotechnol., 2004, 2, 189-194.

9. Xia, Z., Anti-browning of mushroom (Agaricus bisporus) Slices by Glutathione during hot air drying. Adv. J. Food Sci. Technol., 2013, 5, 1100-1104.

10. Aitken, M. D.; Massey, I. J.; Chen, T.; Heck, P. E., Characterization of Reaction Products from The Enzyme Catalyzed Oxidation of Phenolic Pollutants. Water Res., 1994, 28, 1879-1889.

11. Edalli, V. A.; Kamanavalli, C. M., Removal of Phenolic Compounds by Mushroom Polyphenol Oxidase from Pleurotus Species. The ecoscan., 2010, 4, 89-92.

12. Mukherjee, S.; Basak, B.; Bhunia, B.; Dey, A.; Mondal, B., Potential use of polyphenol oxidases (PPO) in the bioremediation of phenolic Contaminants Containing Industrial Wastewater. Rev. Environ. Sci. Biotechnol., 2013, 12, 61-73.

13. Öz, F.; Colak, A.; Özel, A.; Salam Ertunga, N.; Sesli, E., Purification and Characterization of a Mushroom Polyphenol Oxidase and its Activity in Organic Solvents. J. Food Biochem., 2013, 37, 36-44.
14. Gauillard, F.; Richard-Forget, F.; Nicolas, F., New Spectrophotometric Assay for Polyphenol Oxidase. Anal. Biochem., 1993, 215, 59-65.

15. Sigma's quality control. Enzymatic Assay of Polyphenol Oxidase (EC 1.14.18.1). 1993:3-5. https://www.sigmaaldrich.com.

16. Dennison, C. A Guide to Protein Isolation. New York, Boston, Dordrecht, London, Moscow: Kluwer Academic Publisher. http:// www.kluweronline.com. 2002.

17. Clesceri L., Standard Methods for the Examination of Water and Wastewater. The Twetie. (C) Copyright 1999 American Public Health Association, American Water Works Association, Water Environment Federation. 1999.

18. Rescigno, A. Detection of laccase, peroxidase, and polyphenol oxidase on a single polyacrylamide gel electrophoresis. Anal. Lett., 1997, 30, 2211-2220.

19. Maranggoni, A. Enzyme Kinetics. John Wiley \& Sons., 2003.

20. Murniati, Anceu., B. B., Gandasasmita, S. \& Nurachman, Z.Synthesis and Characterization of Polypyrole on Steel Gauze Electrode by Voltammetry Cyclic Method. Indones. J. Mater. Sci., 2012, 13, 210-215.

21. Wang, J. Analytical Electrochemistry. A john Willey \& sons, Ltd. Publication., 2000.

22. Murniati, A.; Buchari, B.; Gandasasmita, S.; Nurachman, Z.; Synthesis and characterization of polypirrole polyphenol oxidase (PPy/PPO) on platinum electrode. Res. J. Pharm. Biol. Chem. Sci., 2012, 3, 855-864. 